\title{
Incorporation of Bacterial Blight Resistance Genes Into Lowland Rice Cultivar Through Marker-Assisted Backcross Breeding
}

\author{
Sharat Kumar Pradhan, Deepak Kumar Nayak, Elssa Pandit, Lambodar Behera, Annamalai Anandan, \\ Arup Kumar Mukherjee, Srikanta Lenka, and Durga Prasad Barik
}

First, second, third, fourth, fifth, sixth, and seventh authors: Crop Improvement Division, National Rice Research Institute, Cuttack, Odisha, India; and eighth author: Department of Botany, Ravenshaw University, Cuttack, Odisha, India.

Accepted for publication 4 March 2016.

\begin{abstract}
Pradhan, S. K., Nayak, D. K., Pandit, E., Behera, L., Anandan, A., Mukherjee, A. K., Lenka, S., and Barik, D. P. 2016. Incorporation of bacterial blight resistance genes into lowland rice cultivar through marker-assisted backcross breeding. Phytopathology 106:710-718.

Bacterial blight $(\mathrm{BB})$ of rice caused by Xanthomonas oryzae pv. oryzae is a major disease of rice in many rice growing countries. Pyramided lines carrying two BB resistance gene combinations $(X a 21+x a 13$ and $\mathrm{Xa21+xa5})$ were developed in a lowland cultivar Jalmagna background through backcross breeding by integrating molecular markers. In each backcross generation, markers closely linked to the disease resistance genes were used to select plants possessing the target genes. Background selection

The BB-pyramided line having the maximum recipient parent genome recovery of $95 \%$ was selected among $\mathrm{BC}_{3} \mathrm{~F}_{1}$ plants and selfed to isolate homozygous $\mathrm{BC}_{3} \mathrm{~F}_{2}$ plants with different combinations of $\mathrm{BB}$ resistance genes. Twenty pyramided lines with two resistance gene combinations exhibited high levels of tolerance against the BB pathogen. In order to confirm the resistance, the pyramided lines were inoculated with different $X$. oryzae pv. oryzae strains of Odisha for bioassay. The genotypes with combination of two BB resistance genes conferred high levels of resistance to the predominant $X$. oryzae pv. oryzae isolates prevalent in the region. The pyramided lines showed similarity with the recipient parent with respect to major agro-morphologic traits.
\end{abstract} was continued in those plants carrying resistant genes until $\mathrm{BC}_{3}$ generation. Plants having the maximum contribution from the recurrent parent genome were selected in each generation and hybridized with the recipient parent.
Additional keywords: foreground selection, gene pyramiding, markerassisted selection.
Bacterial blight (BB), caused by Xanthomonas oryzae pv. oryzae, is one of the most destructive diseases of rice in the major ricegrowing countries of the world. BB causes major losses in the rainfed lowland rice area that covers around 16 million ha in India of which majority are located in the eastern region of the country, exhibiting a lower productivity level (Ismail et al. 2013). The country needs additional rice production of around 2 million tons annually and a total of 135 to 140 million tons by 2030 to maintain self-sufficiency. This production increase needs to be obtained from less land, less water, less labor, and fewer chemicals under the constant threat of new emerging pathogens and pests and possible adverse effects of climate change (Khush 2005). BB is a serious problem of lowland rice, which gets further triggered by application of high dosages of nitrogenous fertilizer for higher yield. Yield losses in rice due to $\mathrm{BB}$ varied from 20 to $80 \%$ depending on location, season, and stage of infection (Khush et al. 1989; Pradhan et al. 2015a, b; Singh et al. 2001; Sonti 1998; Suh et al. 2013). Therefore, breeding for disease resistance was considered to be the most effective, environmental friendly, and economical means to manage $\mathrm{BB}$ of rice.

Globally, 39 BB resistance genes have been identified from diverse sources (Zhang et al. 2014). Many of these genes have been tagged by closely linked molecular markers (Gu et al. 2008; Rao et al. 2002; Sonti 1998; Yoshimura et al. 1995). Among them, 11 are recessive in nature $(x a 5, x a 5(t), x a 8, x a 13, x a 15, x a 19, x a 20, x a 24$, $x a 28, x a 31$, and $x a 32)$ and the remaining 28 are dominant genes. Nine resistance genes (Xa1, Xa3, xa5, Xa10, xa13, Xa21, Xa25,

Corresponding author: S. K. Pradhan; E-mail address: pradhancrri@gmail.com

http://dx.doi.org/10.1094/PHYTO-09-15-0226-R

(C) 2016 The American Phytopathological Society
$\mathrm{Xa27}$, and $\mathrm{Xa38}$ ) have been cloned, following a map-based cloning approach (Bhasin et al. 2012; Chu et al. 2006; Han et al. 2014; Singh et al. 2001). Several germplasm donors carrying diverse genes for $\mathrm{BB}$ resistance have been used to develop BB resistant varieties (Pradhan et al. 2015b).

Large-scale and long-term cultivation of varieties to the single gene may enable the pathogen to overcome BB resistance. However, this can be delayed by pyramiding multiple resistance genes into a popular variety susceptible to $\mathrm{BB}$. The probability of simultaneous transfer of more than one gene through conventional breeding approach is difficult. The availability of molecular markers closely linked with resistance gene help to identify plants with multiple resistance genes. The chance of pathogen mutation to overcome two or more BB resistant genes is much lower than that for a single $\mathrm{BB}$ resistant gene present in a rice cultivar. Pyramiding of two $\mathrm{BB}$ resistance gene combinations in a single line confers widespectrum durable resistance. Tightly linked DNA markers have been developed for several BB resistance genes and are widely used in marker-assisted selection (Bharatkumar et al. 2008; Dokku et al. 2013; Hu et al. 2008; Huang et al. 1997; Joseph et al. 2004; Perez et al. 2008; Pha and Lang 2004; Pradhan et al. 2015b; Rajpurohit et al. 2011; Sanchez et al. 2000; Shanti et al. 2001; Singh et al. 2001; Suh et al. 2013; Sundaram et al. 2008). We report here the successful pyramiding of two BB resistance genes, Xa21 with $x a 5$ and $x a 13$ through marker-assisted selection in a lowland $\mathrm{BB}$-susceptible rice cultivar Jalmagna.

\section{MATERIALS AND METHODS}

Plant materials. The donor parent CRMAS 2232-85, a derivative of a cross Swarna $\times$ IRBB 60 containing BB resistance genes $x a 5, x a 13$, and $X a 21$ in the background of a mega variety Swarna, 
was developed at the National Rice Research Institute (NRRI), Cuttack, India (Pradhan et al. 2015a, b). Jalmagna, the recurrent parent, is a popular variety of the water-logged ecosystem of India but highly susceptible to BB. Jalmagna was hybridized with CRMAS 2232-85 during the wet season in 2010 and the true $F_{1}$ plants were backcrossed with recipient parent Jalmagna in the dry season in 2011 under rapid generation advancement (RGA) facility. Around 360 $\mathrm{BC}_{1} \mathrm{~F}_{1}$ seeds were generated and they were subjected to foreground selection with markers of three resistance genes (Table 1), and the positive plants were employed for background selection. $\mathrm{BC}_{1} \mathrm{~F}_{1}$ line with maximum recurrent genome content was hybridized with recurrent parent to generate $\mathrm{BC}_{2} \mathrm{~F}_{1}$. A Total of $122 \mathrm{BC}_{2} \mathrm{~F}_{1}$ plants were developed during the wet season in 2011. Similarly, $285 \mathrm{BC}_{3} \mathrm{~F}_{1}$ seeds were generated during the dry season in 2012 under RGA facility. The foreground selection positive plant possessing maximum recipient genome content was selfed to produce $\mathrm{BC}_{3} \mathrm{~F}_{2}$ generation seeds during the wet season in 2012. Foreground selection was again continued in $\mathrm{BC}_{3} \mathrm{~F}_{3}$ to confirm homozygous lines for the target gene combinations. The RGA facility was used during the dry season because Jalmagna is a strongly photo-sensitive and long-duration variety.

DNA isolation and PCR amplification. A mini-scale standard DNA preparation isolation protocol was followed (Dellaporta and Wood 1983). The PCR reaction mixture contained $50 \mathrm{ng}$ of templates DNA, 5 picomole of each of the primers, $200 \mu \mathrm{M} d$ NTPs, $1 \times$ PCR buffer (10 mM Tris- $\mathrm{HCl}, \mathrm{pH} 8.3,50 \mathrm{mM} \mathrm{KCl}, 1.5 \mathrm{mM} \mathrm{MgCl}_{2}$, and gelatin at $0.01 \mathrm{mg} / \mathrm{ml}$ ), and 0.6 unit of Taq DNA polymerase in a volume of $20 \mu \mathrm{l}$ and amplification of target sequences were as per earlier reports (Table 1). The PCR products of sequence-tagged site marker RG136 were digested with restriction enzyme HinfI as per manufacturer's instructions. The PCR products and the DNA fragments produced by restriction digestions were separated by gel electrophoresis and gel images were captured by the gel documentation system (SynGene, Germany).

Marker analysis. The publicly available, three tightly linked markers of target genes were used for foreground selection (Table 1). Among the 236 SSR markers used for parental polymorphism survey, 120 were found to be polymorphic between the parents, and 60 were used (four to six per chromosome) for background selection. Data were analyzed and similarity matrix was constructed from binary data with Jaccard's coefficients. The dendrogram was generated with unweighted pair group method arithmetic average (UPGMA) algorithm, using FreeTree software (Hampl et al. 2001; Pavalíce et al. 1999), and the dendrograms were visualized by Treeview 32 software (Page 1996). Graphical Geno Types (GGT) Version 2.0 (Van Berloo 1999) software program was used for the assessment of the genomic contribution of the parent in the selected recombinants based on SSR marker data.

Bioassay. Forty-day-old pyramided plants carrying BB resistant genes in combinations, along with the control, were inoculated with eight isolates of $X$. oryzae pv. oryzae (Kauffman et al. 1973). Eight highly virulent isolates of $X$. oryzae pv. oryzae identified based on their reaction against near isogenic line differentials carrying resistance genes $\mathrm{Xa3}, \mathrm{Xa4}$, Xa5, $\mathrm{Xa7}, \mathrm{Xa10}$, and $\mathrm{Xa} 21$ maintained at National Rice Research Institute, Cuttack, Odisha, India were used for bioassay. The $X$. oryzae pv. oryzae isolates were prepared by suspending the bacterial mass in sterile water to a concentration of approximately $10^{9}$ cells ml-1 (Kauffman et al. 1973). Four leaves from four different plants of each entry were clip-inoculated at the maximum tillering stage and lesion lengths (LL) were recorded after 15 days. The disease symptoms were scored as resistant $(\mathrm{R}$, $\mathrm{LL} \leq 3.0 \mathrm{~cm}$ ), moderately resistant (MR, LL $3.0 \mathrm{~cm} \leq 6.0 \mathrm{~cm})$, moderately susceptible (MS, LL $6.0 \mathrm{~cm} \leq 9.0 \mathrm{~cm}$ ), or susceptible

TABLE 1. Markers used for foreground selection for three bacterial blight resistance genes in marker-assisted backcross breeding

\begin{tabular}{|c|c|c|c|c|c|c|c|}
\hline \multirow{2}{*}{$\begin{array}{l}\text { Resistance } \\
\text { gene }\end{array}$} & \multirow{2}{*}{$\begin{array}{l}\text { Chromosome } \\
\text { number }\end{array}$} & \multirow[b]{2}{*}{ Marker } & \multicolumn{2}{|c|}{ Primer sequences used for gene detection } & \multirow[b]{2}{*}{ Expected size (bp) } & \multirow{2}{*}{$\begin{array}{l}\text { Band } \\
\text { type }\end{array}$} & \multirow[b]{2}{*}{ Reference } \\
\hline & & & Forward $\left(5^{\prime}-3^{\prime}\right)$ & Reverse $\left(5^{\prime}-3^{\prime}\right)$ & & & \\
\hline \multirow[t]{2}{*}{$x a 5$} & 5 & xa5S (multiplex) & $\begin{array}{c}\text { GTCTGGAATTTG } \\
\text { CTCGCGTTCG }\end{array}$ & $\begin{array}{r}\text { TGGTAAAGTAGATAC } \\
\text { CTTATCAAACTGGA }\end{array}$ & 410 bp, 310 bp, 180 bp & STS & Sundaram et al. 2011 \\
\hline & & $\begin{array}{l}\text { xa5SR/R } \\
\text { (multiplex) }\end{array}$ & $\begin{array}{r}\text { AGCTCGCCATTC } \\
\text { AAGTTCTTGAG }\end{array}$ & $\begin{array}{c}\text { TGACTTGGTTCT } \\
\text { CCAAGGCTT }\end{array}$ & & & Pradhan et al. $2015 b$ \\
\hline xal3 & 8 & RG136 & $\begin{array}{l}\text { TCCCAGAAAGCT } \\
\text { ACTACAGC }\end{array}$ & $\begin{array}{l}\text { GCAGACTCCAGT } \\
\text { TTGACTTC }\end{array}$ & $530 \mathrm{bp}, 490 \mathrm{bp}$ & STS & Huang et al. 1997 \\
\hline$X a 21$ & 11 & pTA248 & $\begin{array}{l}\text { AGACGCGGAAGG } \\
\text { GTGGTTCCCGGA }\end{array}$ & $\begin{array}{l}\text { AGACGCGGTAATC } \\
\text { GAAGATGAAA }\end{array}$ & $1,000 \mathrm{bp}$ & STS & Huang et al. 1997 \\
\hline
\end{tabular}

TABLE 2. Microsatellite markers are polymorphic between Jalmagna and CRMAS 2232-85

\begin{tabular}{|c|c|c|c|}
\hline Chromosome & $\begin{array}{l}\text { Number of } \\
\text { markers analyzed }\end{array}$ & $\begin{array}{l}\text { Total number of } \\
\text { polymorphic markers }\end{array}$ & Name of the polymorphic markers \\
\hline 1 & 25 & 11 & $\begin{array}{l}\text { RM23, RM48, RM212, RM272, RM575, RM428, RM488, SSR09, SSR 31, } \\
\text { SSR 60, SSR } 71\end{array}$ \\
\hline 2 & 25 & 12 & $\begin{array}{l}\text { RM154, RM211, RM233A, RM263, RM475, RM45, RM530,SSR11, SSR 14, } \\
\text { SSR 44, SSR 71, SSR 85 }\end{array}$ \\
\hline 3 & 21 & 10 & $\begin{array}{l}\text { RM16, RM130, RM218, RM203, SSR 06, SSR 13, SSR 18, SSR 45, SSR 85, } \\
\text { SSR } 93\end{array}$ \\
\hline 4 & 18 & 12 & $\begin{array}{l}\text { RM241, RM307, RM401, RM55, RM471, RM518, RM470, SSR 04, SSR } 10 \text {, } \\
\text { SSR 19, SSR 32, SSR } 40\end{array}$ \\
\hline 5 & 19 & 12 & $\begin{array}{l}\text { RM164, RM592, RM440, SSR 05, SSR 13, SSR 21, SSR 27, SSR 34,SSR 37, } \\
\text { SSR 43, SSR 50, SSR } 59\end{array}$ \\
\hline 6 & 20 & 10 & $\begin{array}{l}\text { RM225, RM276, RM340, RM402, RM586, RM589, RM588, SSR 21, SSR 31, } \\
\text { SSR 54 }\end{array}$ \\
\hline 7 & 21 & 9 & RM10, RM336, RM560, RM432, RM346, SSR 28, SSR 37, SSR 41, SSR 44 \\
\hline 8 & 20 & 10 & $\begin{array}{l}\text { RM223, RM241, RM407, RM3395, RM6208, RM22550, RM22506, RM8271, } \\
\text { SSR 14, SSR } 48\end{array}$ \\
\hline 9 & 16 & 7 & RM219, RM242, RM257, RM410, RM3555, SSR 40, SSR 42 \\
\hline 10 & 17 & 9 & RM171, RM216, RM333, RM330, SSR 03, SSR 06, SSR 11, SSR 25, SSR 30 \\
\hline 11 & 18 & 11 & $\begin{array}{l}\text { RM21, RM144, M202, RM206, RM209, RM260, RM287, SSR 3, SSR 4, } \\
\text { SSR 11, SSR } 27\end{array}$ \\
\hline 12 & 17 & 7 & RM17, RM195, RM415, RM23, SSR 23, SSR 26, SSR 36 \\
\hline Total & 236 & 120 & \\
\hline
\end{tabular}


$(\mathrm{S}, \mathrm{LL}>9.0 \mathrm{~cm}$ ) (Amante-Bordeos et al. 1992). The standard error for lesion length measurements were estimated using Microsoft excel software.

Characterization for agro-morphological traits. Thirtyday-old seedlings of the $\mathrm{BC}_{3} \mathrm{~F}_{3}$ pyramided lines and both the parents were transplanted in five rows with 20 plants per row per entry at $15 \times 20 \mathrm{~cm}$ spacing under a randomized complete block design with two replications at the experimental farm of NRRI, Cuttack, during the wet season in 2014. Data were recorded on 10 plants from each entry and replication for agronomic traits (plant height $[\mathrm{cm}]$, tillers/plant, panicle length [cm], number of filled grains/panicle, 1,000-grain weight [g], spikelet fertility [\%], grain length [mm], grain breadth $[\mathrm{mm}]$, flag leaf length $[\mathrm{cm}]$, and flag leaf breadth $[\mathrm{cm}]$ ), while days to $50 \%$ flowering was recorded on whole plot basis. Analysis of variance for various agro-morphologic traits and principal component analysis (PCA) were performed using SAS statistical software (SAS Institute Inc. 2010).

\section{RESULTS}

Pyramiding of BB resistance genes. The molecular markers used in the foreground selection (Table 1) for selecting the genotypes with the target genes $X a 21, x a 13$, and $x a 5$ were first validated by confirming the polymorphism obtained with pTA248, RG136 and xa5S, R (multiplex) in the donor (CRMAS 2232-85) and recurrent parent (Jalmagna). In addition, the parents were screened with 236 rice microsatellite markers (Table 2 ) of which 120 were polymorphic and 60 among them were used for background selection.

Marker-assisted breeding program was integrated in the conventional backcross breeding until $\mathrm{BC}_{3} \mathrm{~F}_{3}$ generation. After hybridization, foreground selection was followed in $\mathrm{F}_{1}$ hybrids to check true hybrids carrying donor segments. The selection in $\mathrm{BC}_{1}$ to $\mathrm{BC}_{3}$ generations for target trait was carried out to select the plants containing resistance alleles of the target genes and only progenies having the resistance alleles were advanced up to $\mathrm{BC}_{3} \mathrm{~F}_{3}$ generation (Fig. 1). Background selection was started from $\mathrm{BC}_{1} \mathrm{~F}_{1}$ and continued up to $\mathrm{BC}_{3} \mathrm{~F}_{1}$ generation. In each backcross generation, genotype possessing maximum genome content of the recipient parent was selected to hybridize with recipient parent for next backcross. A representative electrophoregram for background selection in the backcross progenies is depicted in Figure 2. A total of $650 \mathrm{~F}_{1}$ plants were produced and $150 \mathrm{~F}_{1}$ plants were tested for the hybridity and 143 hybrid plants were confirmed by their heterozygosity for the resistance gene linked markers. The true $\mathrm{F}_{1} \mathrm{~s}$ were backcrossed
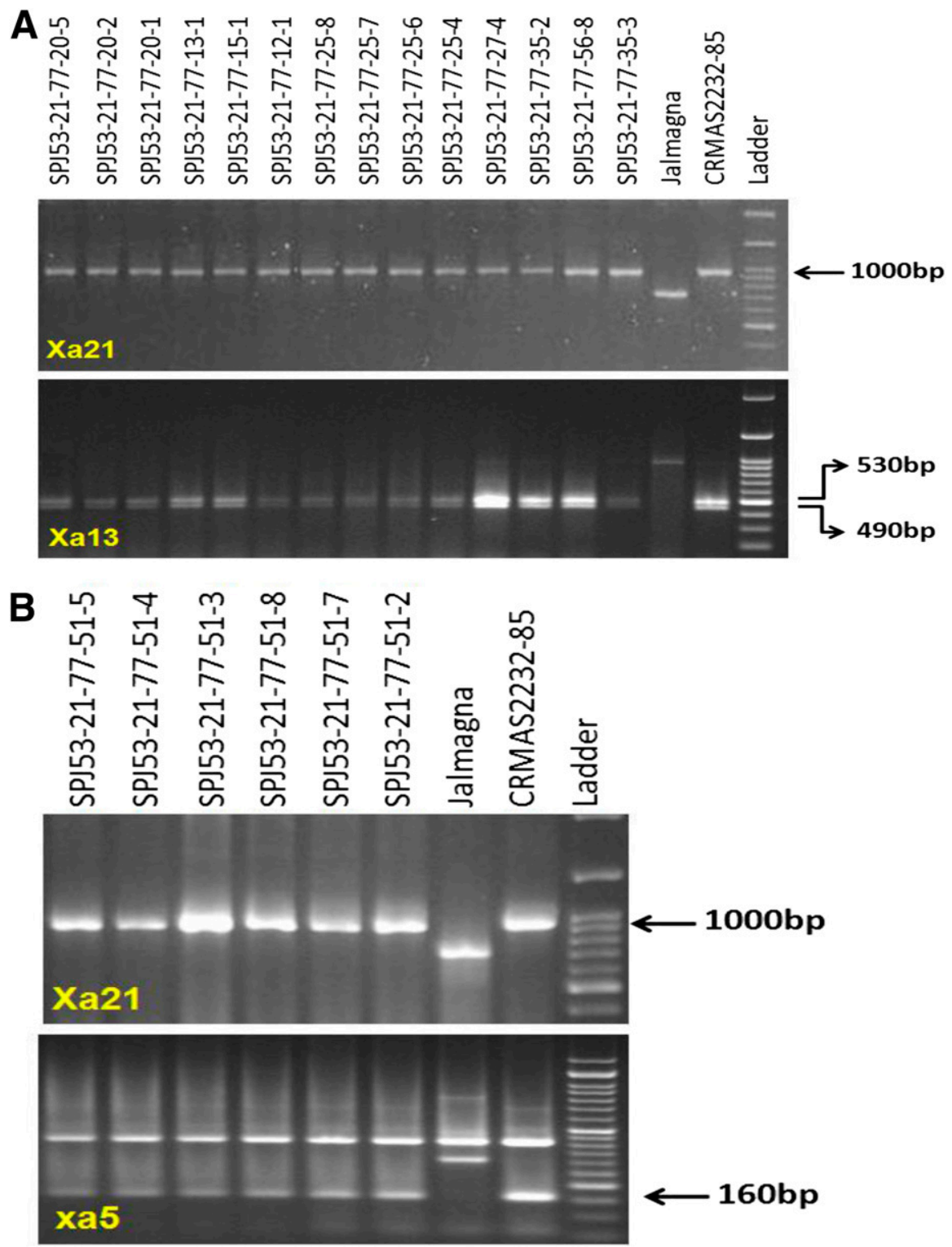

Fig. 1. PCR amplification of markers linked to resistance genes A, Xa21 and $x a 13$ and $\mathbf{B}, X a 21$ and $x a 5$ using primers pAT248, RG136, and xa5S and xa5R for resistance genes $\mathrm{Xa21}$, xa13, and $x a 5$, respectively, in $\mathrm{BC}_{3} \mathrm{~F}_{3}$ pyramided lines. Molecular weight marker for Xa21 and $x a 13$ (100-bp ladder) and $x a 5$ (50-bp ladder). 
with the recipient parent to get $\mathrm{BC}_{1} \mathrm{~F}_{1}$ generation seeds. These crossed seeds were raised for further backcrossing with recurrent parent. Ninety-three plants showed the presence of $\mathrm{Xa21}$ resistance genespecific bands $(1,000 \mathrm{bp}), 113$ plants for the presence of $x a 5$ resistance gene-specific bands (160 bp), while 91 plants showed the presence of $x a 13$ resistance gene-specific bands ( 490 and $530 \mathrm{bp}$ ) in the $\mathrm{BC}_{1} \mathrm{~F}_{1}$ generation. Based on the amplification of resistance specific bands, $31 \mathrm{BC}_{1} \mathrm{~F}_{1}$ plants showed the presence of $\mathrm{Xa21}$ and $x a 13$ resistance genes, while $42 \mathrm{BC}_{1} \mathrm{~F}_{1}$ plants showed the presence of Xa21 and $x a 5$ resistance genes. Forty-six $\mathrm{BC}_{1} \mathrm{~F}_{1}$ plants showed the presence of $x a 13$ and $x a 5$ resistance genes. Only 14 plants showed the presence of three $\mathrm{BB}$ resistance genes (Xa21, xa13, and $x a 5)$. Out of these 14 $\mathrm{BC}_{1} \mathrm{~F}_{1}$ progenies, the plant showing $77.5 \%$ of recurrent genome (plant no. 53) was backcrossed with recurrent parent Jalmagna.
The foreground selection in $122 \mathrm{BC}_{2} \mathrm{~F}_{1}$ generation progenies revealed the presence of 21,33 , and 30 progenies containing resistance genes $X a 21, x a 13$, and $x a 5$, respectively. Based on the genotyping data, $11 \mathrm{BC}_{2} \mathrm{~F}_{1}$ plants showed the presence of $X a 21$ and xal3 resistance genes while $13 \mathrm{BC}_{2} \mathrm{~F}_{1}$ plants showed the presence of $\mathrm{Xa21}$ and $x a 5$ resistance genes. Twenty-three $\mathrm{BC}_{2} \mathrm{~F}_{1}$ plants showed the presence of $x a 13$ and $x a 5$ resistance genes. From the genotyping analysis, nine plants exhibited the presence of three resistance genes $(\mathrm{Xa21}, \mathrm{xa13}$, and $\mathrm{xa5})$. The background selection of these nine $\mathrm{BC}_{2} \mathrm{~F}_{1}$ plants with 60 polymorphic SSR markers exhibited the presence of 88.13 to $91.82 \%$ with an average of $90.95 \%$ of recipient parent genome content. The plant containing 91.82\% genome content of Jalmagna (plant no. 53-21) was used for backcrossing.
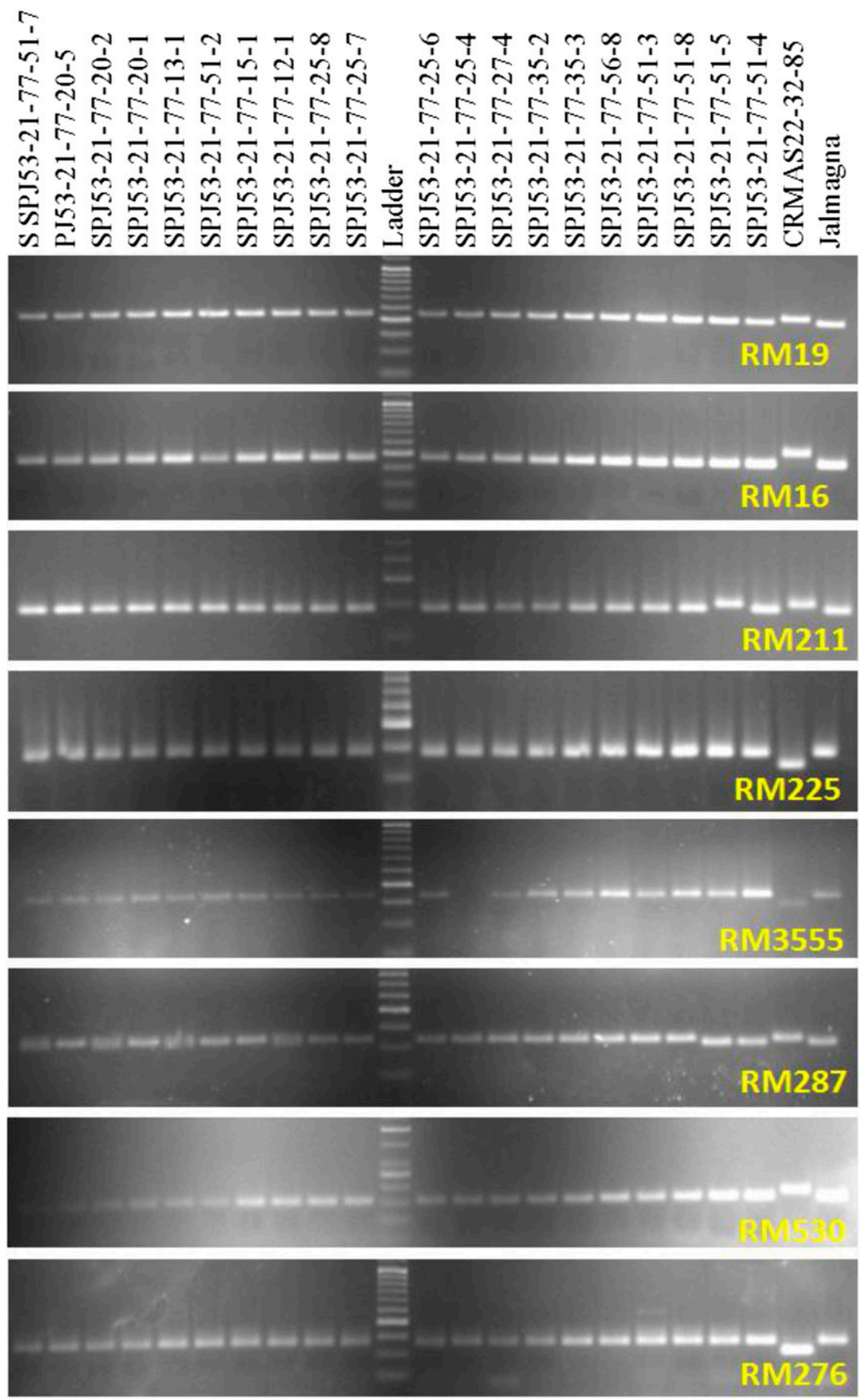

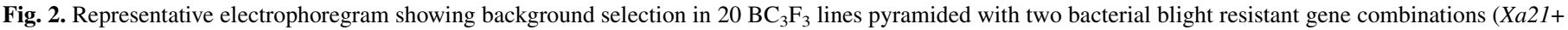
$x a 13$ and $X a 21+x a 5)$ along with parents using microsatellite markers. 
A total of $285 \mathrm{BC}_{3} \mathrm{~F}_{1}$ backcross derivatives were generated by hybridizing the plant carrying $91.82 \%$ of recurrent genome with the recipient parent. Genotyping analysis of $\mathrm{BC}_{3} \mathrm{~F}_{1}$ plants exhibited a total of 28 plants positive for $\mathrm{Xa21,35}$ for $x a 5$, and 14 for $x a 13$. Eighteen $\mathrm{BC}_{3} \mathrm{~F}_{1}$ plants showed the presence of $\mathrm{Xa21}$ and $\mathrm{xa} 13$ resistance genes while 14 plants showed the presence of $\mathrm{Xa21}$ and $x a 5$ resistance genes. These $\mathrm{BC}_{3} \mathrm{~F}_{1}$ plants showed recipient parent genome content ranging from 91.7 to $95 \%$ with an average of $93.2 \%$. During $\mathrm{BC}_{3} \mathrm{~F}_{2}$ genotyping analysis, plants homozygous for two $\mathrm{BB}$ resistance gene combinations were selected and advanced to next generation, $\mathrm{BC}_{3} \mathrm{~F}_{3}$. Xa21 and $x a 5$ gene combination was noticed in six lines, while 14 plants exhibited combination of $\mathrm{Xa21}$ and $x a 13$ resistance genes. The $\mathrm{BC}_{3} \mathrm{~F}_{3}$ derivatives carrying gene combination of $\mathrm{Xa21}+x a 13$ and showing $95 \%$ recipient genome content were observed to be SPJ 53-21-77-13-1, SPJ 53-21-77-25-4, and SPJ 53-21-77-56-8 (Table 3). Pyramided lines with Xa21+xa5 gene combination also exhibited $95 \%$ genome contribution from recipient parent in SPJ 53-21-77-51-2 and SPJ 53-21-77-51-4 (Table 3).

Bioassays. The resistance and susceptibility reaction of the pyramided lines, donor and recipient parents to BB lesions were analyzed under artificial inoculation condition for confirmation of the results. The donor parent showed low average lesion lengths $(2.1$ to $2.8 \mathrm{~cm})$ while the recurrent parent Jalmagna had longer lesion lengths $(9.4$ to $12.8 \mathrm{~cm}$ ) (Table 4). The phenotypic results indicated that the pyramided lines were more resistant than the recurrent parent. The lesion lengths observed from the lines containing Xa21+xa13 gene combination varied from 3.1 to $5.9 \mathrm{~cm}$, while $X a 21+x a 5$ gene combination showed a range of 3.9 to $6.0 \mathrm{~cm}$. Though all the gene combinations tested did not show any susceptible reaction to any of the eight isolates, the gene pyramids with $\mathrm{Xa21+}$ $x a 13$ and $X a 21+x a 5$ genes displayed higher levels of disease resistance with shorter lesion lengths against all $\mathrm{BB}$ isolates. Results indicated that the degree of severity of the disease from the data, the

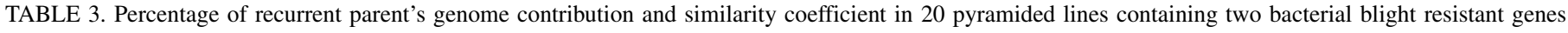

\begin{tabular}{|c|c|c|c|c|}
\hline Sl number & Pyramided lines & Gene combination & $\begin{array}{l}\text { Recurrent parent's genome } \\
\text { contribution }(\%)\end{array}$ & $\begin{array}{l}\text { Similarity coefficient with } \\
\text { recurrent parent }\end{array}$ \\
\hline 1 & SPJ 53-21-77-20-5 & $X a 21+x a 13$ & 93.3 & 0.93 \\
\hline 2 & SPJ 53-21-77-20-2 & $X a 21+x a 13$ & 93.3 & 0.93 \\
\hline 3 & SPJ 53-21-77-20-1 & $X a 21+x a 13$ & 93.3 & 0.95 \\
\hline 4 & SPJ 53-21-77-13-1 & $X a 21+x a 13$ & 95.0 & 0.93 \\
\hline 5 & SPJ 53-21-77-15-1 & $X a 21+x a 13$ & 93.3 & 0.95 \\
\hline 6 & SPJ 53-21-77-12-1 & $X a 21+x a 13$ & 91.7 & 0.95 \\
\hline 7 & SPJ 53-21-77-25-8 & $X a 21+x a 13$ & 91.7 & 0.93 \\
\hline 8 & SPJ 53-21-77-25-7 & $X a 21+x a 13$ & 91.7 & 0.92 \\
\hline 9 & SPJ 53-21-77-25-6 & $X a 21+x a 13$ & 91.7 & 0.92 \\
\hline 10 & SPJ 53-21-77-25-4 & $X a 21+x a 13$ & 95.0 & 0.92 \\
\hline 11 & SPJ 53-21-77-27-4 & $X a 21+x a 13$ & 91.7 & 0.92 \\
\hline 12 & SPJ 53-21-77-35-2 & $X a 21+x a 13$ & 91.7 & 0.95 \\
\hline 13 & SPJ 53-21-77-56-8 & $X a 21+x a 13$ & 95.0 & 0.92 \\
\hline 14 & SPJ 53-21-77-35-3 & $X a 21+x a 13$ & 93.3 & 0.92 \\
\hline 15 & SPJ 53-21-77-51-5 & $X a 21+x a 5$ & 91.7 & 0.93 \\
\hline 16 & SPJ 53-21-77-51-4 & $X a 21+x a 5$ & 95.0 & 0.95 \\
\hline 17 & SPJ 53-21-77-51-3 & $X a 21+x a 5$ & 93.3 & 0.93 \\
\hline 18 & SPJ 53-21-77-51-8 & $X a 21+x a 5$ & 93.3 & 0.93 \\
\hline 19 & SPJ 53-21-77-51-7 & $X a 21+x a 5$ & 93.3 & 0.92 \\
\hline 20 & SPJ 53-21-77-51-2 & $X a 21+x a 5$ & 95.0 & 0.95 \\
\hline 21 & CRMAS 2232-85 & $X a 13+X a 21+x a 5$ & 0.0 & 0.00 \\
\hline 22 & Jalmagna & - & 100.0 & 100.00 \\
\hline
\end{tabular}

TABLE 4. Bacterial blight disease reaction of parental and $\mathrm{BC}_{3} \mathrm{~F}_{3}$ pyramided lines against different Xanthomonas oryzae pv. oryzae strains

\begin{tabular}{|c|c|c|c|c|c|c|c|c|c|c|c|}
\hline \multirow{2}{*}{$\begin{array}{l}\text { Sl } \\
\text { number }\end{array}$} & \multirow{2}{*}{$\begin{array}{c}\text { Pyramided lines } / X \text {. oryzae } \\
\text { pv. oryzae strains }\end{array}$} & \multirow{2}{*}{$\begin{array}{c}\text { Gene } \\
\text { combination }\end{array}$} & \multicolumn{8}{|c|}{ Mean lesion length in $\mathrm{cm}$ (mean \pm standard error) } & \multirow{2}{*}{$\begin{array}{l}\text { Disease } \\
\text { reaction }^{\text {a }}\end{array}$} \\
\hline & & & Хa-17 & $\mathrm{Xa}-7$ & xa-2 & $\mathrm{xb}-7$ & $\mathrm{xc}-4$ & $\mathrm{xd}-1$ & xa-1 & xa-5 & \\
\hline 1 & SPJ 53-21-77-20-5 & $X a 21+x a 13$ & $3.6 \pm 0.44$ & $3.4 \pm 1.12$ & $3.5 \pm 1.12$ & $3.1 \pm 0.65$ & $3.4 \pm 0.74$ & $3.7 \pm 0.46$ & $3.6 \pm 1.20$ & $3.7 \pm 0.63$ & MR \\
\hline 2 & SPJ 53-21-77-20-2 & $X a 21+x a 13$ & $3.9 \pm 0.54$ & $3.8 \pm 1.21$ & $3.6 \pm 1.14$ & $3.7 \pm 0.55$ & $3.7 \pm 0.92$ & $3.8 \pm 0.77$ & $3.4 \pm 1.13$ & $3.9 \pm 0.7$ & MR \\
\hline 3 & SPJ 53-21-77-20-1 & $X a 21+x a 13$ & $4.1 \pm 0.46$ & $4.3 \pm 0.64$ & $3.9 \pm 0.83$ & $3.6 \pm 0.46$ & $3.8 \pm 0.65$ & $3.6 \pm 0.52$ & $4.1 \pm 0.39$ & $3.9 \pm 0.65$ & MR \\
\hline 4 & SPJ 53-21-77-13-1 & $X a 21+x a 13$ & $5.2 \pm 0.63$ & $4.4 \pm 0.61$ & $3.8 \pm 0.75$ & $3.9 \pm 0.52$ & $4.2 \pm 0.44$ & $4.3 \pm 0.55$ & $5.8 \pm 0.78$ & $4.3 \pm 1.14$ & MR \\
\hline 5 & SPJ 53-21-77-15-1 & $X a 21+x a 13$ & $4.5 \pm 0.72$ & $3.1 \pm 0.42$ & $3.4 \pm 0.61$ & $4.2 \pm 0.44$ & $4.1 \pm 0.53$ & $4.5 \pm 0.61$ & $5.6 \pm 0.48$ & $4.6 \pm 0.88$ & MR \\
\hline 6 & SPJ 53-21-77-12-1 & $X a 21+x a 13$ & $4.7 \pm 0.68$ & $4.2 \pm 0.53$ & $4.1 \pm 0.72$ & $4.6 \pm 0.54$ & $4.3 \pm 0.49$ & $4.7 \pm 0.52$ & $4.3 \pm 0.65$ & $4.3 \pm 0.72$ & MR \\
\hline 7 & SPJ 53-21-77-25-8 & $X a 21+x a 13$ & $4.2 \pm 0.51$ & $4.7 \pm 0.62$ & $4.3 \pm 0.67$ & $4.5 \pm 0.57$ & $4.1 \pm 0.57$ & $4.2 \pm 0.68$ & $4.5 \pm 0.57$ & $4.4 \pm 0.66$ & MR \\
\hline 8 & SPJ 53-21-77-25-7 & $X a 21+x a 13$ & $5.3 \pm 0.45$ & $5.1 \pm 0.58$ & $5.2 \pm 0.55$ & $5.1 \pm 0.63$ & $4.7 \pm 0.73$ & $4.5 \pm 0.71$ & $4.6 \pm 0.69$ & $4.7 \pm 0.73$ & MR \\
\hline 9 & SPJ 53-21-77-25-6 & $X a 21+x a 13$ & $4.9 \pm 0.53$ & $5.4 \pm 0.46$ & $5.4 \pm 0.53$ & $5.5 \pm 0.88$ & $5.1 \pm 0.92$ & $5.0 \pm 0.81$ & $4.8 \pm 0.77$ & $4.9 \pm 0.55$ & MR \\
\hline 10 & SPJ 53-21-77-25-4 & $X a 21+x a 13$ & $5.2 \pm 0.76$ & $5.4 \pm 0.38$ & $5.2 \pm 0.83$ & $5.5 \pm 0.74$ & $5.7 \pm 0.92$ & $5.2 \pm 0.82$ & $4.7 \pm 0.88$ & $5.3 \pm 0.66$ & MR \\
\hline 11 & SPJ 53-21-77-27-4 & $X a 21+x a 13$ & $5.3 \pm 0.36$ & $5.3 \pm 0.75$ & $5.2 \pm 0.77$ & $5.4 \pm 0.68$ & $5.3 \pm 0.51$ & $5.4 \pm 0.67$ & $5.7 \pm 0.36$ & $5.3 \pm 0.59$ & MR \\
\hline 12 & SPJ 53-21-77-35-2 & $X a 21+x a 13$ & $5.6 \pm 0.43$ & $4.7 \pm 0.98$ & $5.5 \pm 0.74$ & $5.6 \pm 0.68$ & $5.7 \pm 0.52$ & $5.5 \pm 0.79$ & $5.4 \pm 0.92$ & $5.6 \pm 0.83$ & MR \\
\hline 13 & SPJ 53-21-77-56-8 & $X a 21+x a 13$ & $5.8 \pm 0.65$ & $5.3 \pm 1.21$ & $5.7 \pm 0.86$ & $5.6 \pm 0.91$ & $5.5 \pm 0.95$ & $5.8 \pm 0.55$ & $5.7 \pm 0.66$ & $5.8 \pm 0.75$ & MR \\
\hline 14 & SPJ 53-21-77-35-3 & $X a 21+x a 13$ & $5.9 \pm 1.06$ & $5.8 \pm 0.93$ & $5.8 \pm 0.71$ & $5.9 \pm 0.72$ & $5.8 \pm 0.83$ & $5.6 \pm 0.63$ & $5.8 \pm 0.62$ & $5.7 \pm 0.87$ & MR \\
\hline 15 & SPJ 53-21-77-51-5 & $X a 21+x a 5$ & $4.8 \pm 0.57$ & $4.7 \pm 1.4$ & $4.9 \pm 0.72$ & $4.5 \pm 0.63$ & $4.7 \pm 1.2$ & $4.3 \pm 0.72$ & $4.2 \pm 0.48$ & $3.9 \pm 0.73$ & MR \\
\hline 16 & SPJ 53-21-77-51-4 & $X a 21+x a 5$ & $4.5 \pm 0.85$ & $4.9 \pm 1.3$ & $5.4 \pm 0.63$ & $4.8 \pm 0.82$ & $4.9 \pm 0.91$ & $4.3 \pm 0.52$ & $4.2 \pm 0.63$ & $5.1 \pm 0.65$ & MR \\
\hline 17 & SPJ 53-21-77-51-2 & $X a 21+x a 5$ & $4.9 \pm 0.55$ & $4.8 \pm 0.63$ & $5.1 \pm 0.56$ & $5.4 \pm 0.71$ & $5.1 \pm 0.92$ & $5.3 \pm 0.60$ & $5.5 \pm 0.69$ & $5.2 \pm 0.43$ & MR \\
\hline 18 & SPJ 53-21-77-51-8 & $X a 21+x a 5$ & $5.6 \pm 0.71$ & $5.4 \pm 0.92$ & $5.8 \pm 0.95$ & $5.9 \pm 1.12$ & $5.8 \pm 1.06$ & $5.4 \pm 0.53$ & $5.3 \pm 0.75$ & $5.6 \pm 0.42$ & MR \\
\hline 19 & SPJ 53-21-77-51-7 & $X a 21+x a 5$ & $5.7 \pm 1.1$ & $5.3 \pm 0.8$ & $5.8 \pm 0.6$ & $5.9 \pm 0.7$ & $5.5 \pm 1.3$ & $5.3 \pm 0.49$ & $5.7 \pm 0.72$ & $4.9 \pm 0.53$ & MR \\
\hline 20 & SPJ 53-21-77-51-3 & $X a 21+x a 5$ & $5.9 \pm 0.7$ & $5.8 \pm 0.8$ & $6.0 \pm 0.7$ & $5.7 \pm 0.7$ & $5.6 \pm 0.9$ & $5.5 \pm 0.76$ & $5.8 \pm 0.84$ & $5.7 \pm 0.65$ & MR \\
\hline 21 & CRMAS 2232-85 & $X a 13+X a 21+x a 5$ & $2.8 \pm 0.4$ & $2.5 \pm 0.3$ & $2.4 \pm 0.4$ & $2.1 \pm 0.4$ & $2.8 \pm 0.5$ & $2.4 \pm 0.4$ & $2.6 \pm 0.8$ & $2.2 \pm 0.6$ & $\mathrm{R}$ \\
\hline 22 & Jalmagna & - & $12.6 \pm 1.7$ & $11.4 \pm 1.4$ & $12.8 \pm 1.5$ & $9.4 \pm 1.2$ & $11.6 \pm 1.6$ & $9.8 \pm 1.8$ & $10.2 \pm 1.7$ & $11.6 \pm 1.8$ & S \\
\hline
\end{tabular}

${ }^{a}$ MR, moderately resistant; R, resistant; and S, susceptible. 
order of gene combinations in conferring resistance was in the trend of $x a 13+X a 21<x a 5+X a 21$.

Yield and agro-morphologic traits of the pyramided lines. The pyramided lines were evaluated along with parents to compare the yield, agro-morphologic and grain quality traits with the recipient variety. Twenty pyramid lines containing two $\mathrm{BB}$ resistance genes at $\mathrm{BC}_{3} \mathrm{~F}_{3}$ generation along with the donor and recipient parents were evaluated during the wet season in 2014 at NRRI, Cuttack. The recipient parent Jalmagna exhibited the mean grain yield of $17.35 \mathrm{~g} / \mathrm{plant}$, while the donor parent (Swarna BB pyramided line) recorded $20.5 \mathrm{~g} /$ plant. All of the test entries with two BB resistance gene combinations showed grain yields higher than recurrent parent Jalmagna (Table 5). Many pyramided lines showed similar agro-morphologic traits like the recipient parent, Jalmagna (Table 5). A dendrogram generated on the basis of 12 agro-morphologic traits of 20 pyramided and two parental lines showed two clusters and all the pyramided lines belonged to a single cluster (cluster II) with the recipient parent, Jalmagna, while the cluster I was a monogenotypic cluster with the genotype CRMAS 2232-85 (Table 5; Fig. 3). The genotype-by-trait biplot generated using 12 agro-morphologic traits of 20 pyramided lines along with parents also showed clearly that the pyramided lines clustered near the origin remaining closer to each other, while the donor parent placed far apart (Fig. 4). Most of the pyramided lines were in the first quadrant along with the recipient parent Jalmagna. The first principal component explained $63.7 \%$ of variation, while the second component exhibited $15.5 \%$ of the total variability. Among the agro-morphologic traits studied, panicle length contributed maximum toward diversity followed by grain length (Fig. 4).

Background selection. Background selection was carried out to accelerate the recovery of recurrent parent's genome content in progenies of various backcross generations. Background selection was performed in the genotypes that were observed to be positive for three target resistance genes using 60 SSR markers in $\mathrm{BC}_{1} \mathrm{~F}_{1}$, $\mathrm{BC}_{2} \mathrm{~F}_{1}$, and $\mathrm{BC}_{3} \mathrm{~F}_{1}$ generations. The genotyping of $\mathrm{BC}_{3} \mathrm{~F}_{1}$ derivatives showed a total of 120 alleles from 60 markers with similarity coefficient ranging from 0.85 to 1.0. A dendrogram generated using the SSR data grouped the 20 pyramid lines with two-gene combinations into two major clusters (Fig. 3B). Cluster I possessed donor parent CRMAS 2232-85 and the rest pyramided lines and the recipient parent were accommodated in cluster II. Nearly all the entries in cluster II were very close to recipient parent Jalmagna with similar Jaccard's coefficient value. Among the 20 pyramided lines observed, $100 \%$ similarity was noticed in SPJ 53-21-77-51-5 with SPJ 53-21-77-25-6 and SPJ 53-21-77-56-8 with SPJ 53-21-77-20-2 on the basis of 60 background primers used (Fig. 3B).

Analysis of genome introgression on the carrier and noncarrier chromosomes. The genotyping of backcross derivatives using five microsatellite markers on each of three carrier chromosomes in the genomic region flanking to $x a 5, x a 13$, and $X a 21$ were polymorphic. The genotypic results for the target genes in the 20 pyramided lines indicated that 14 of the pyramided lines showed homozygosity for the target segment of $x a 13$ and Xa21. No drag was observed in xal3 carrying chromosome but a donor segment was observed between marker RM287 and pTA248 for Xa21 carrier chromosome in all 14 pyramided lines (Fig. 5A). The genotyping results of six pyramided lines carrying target genes $X a 21$ and $x a 5$ exhibited no drag in four lines (SPJ 53-21-77-51-4, SPJ 53-21-77-51-5, SPJ 53-21-77-51-7, and SPJ 53-21-77-51-8) for $x a 5$ carrier chromosome while a donor segment observed between marker HYV 5-27 and HYV 5-43 in the rest of two pyramids (SPJ 53-21-77-51-2 and SPJ 53-21-77-51-3) (Fig. 5B). In the introgression analysis of $\mathrm{Xa} 21$ carrier chromosome, it was observed that five pyramided lines showed no introgression from donor segment while a chromosomal segment drag was observed between markers HYV11-3 and RM 287 in the pyramided line SPJ 53-21-77-51-7 (Fig. 5A).

\section{DISCUSSION}

Integration of molecular markers in the backcross breeding increases the precision in transferring the desired gene(s) to the recipient variety, as well as reduces the duration of selection cycle compared with conventional backcross breeding. Phenotypic selections in three backcross generations followed by two selfing generations were sufficient to transfer two BB resistance genes into the lowland cultivar Jalmagna background. Jalmagna is a popular lowland rice of about 160-day duration with strong photo-sensitivity. Control of BB using chemicals under waterlogged ecology is a relatively difficult task. Therefore, development of BB tolerant lines

TABLE 5. Agro-morphologic traits of parental and selected $\mathrm{BC}_{3} \mathrm{~F}_{3}$ pyramided lines

\begin{tabular}{|c|c|c|c|c|c|c|c|c|c|c|c|c|c|}
\hline $\begin{array}{l}\text { S1 } \\
\text { number }\end{array}$ & Pyramided lines & $\begin{array}{l}\text { Plant } \\
\text { height } \\
(\mathrm{cm})\end{array}$ & $\begin{array}{l}\text { Days to } \\
50 \% \text { flow }\end{array}$ & $\begin{array}{c}\text { panicles/ } \\
\text { plant }\end{array}$ & $\begin{array}{l}\text { Panicle } \\
\text { length } \\
(\mathrm{cm})\end{array}$ & $\begin{array}{c}\text { Number of } \\
\text { grains/ } \\
\text { panicle }\end{array}$ & $\begin{array}{c}\text { Fertility } \\
\%\end{array}$ & $\begin{array}{l}\text { 1,000-seed } \\
\text { weight }(\mathrm{g})\end{array}$ & $\begin{array}{l}\text { Single } \\
\text { plant } \\
\text { yield }(\mathrm{g})\end{array}$ & $\begin{array}{l}\text { Grain } \\
\text { length } \\
(\mathrm{mm})\end{array}$ & $\begin{array}{l}\text { Grain } \\
\text { Breadth } \\
(\mathrm{mm})\end{array}$ & $\begin{array}{l}\text { Flag leaf } \\
\text { length } \\
(\mathrm{cm})\end{array}$ & $\begin{array}{c}\text { Flag leaf } \\
\text { breadth } \\
(\mathrm{cm})\end{array}$ \\
\hline 1 & SPJ 53-21-77-20-5 & 152 & 128 & 10 & 23.95 & 205.5 & 88.2 & 23.15 & 19.15 & 0.75 & 0.865 & 32.0 & 1.6 \\
\hline 2 & SPJ 53-21-77-20-2 & 173 & 126 & 10.2 & 23.1 & 204.2 & 87.5 & 23.35 & 18.85 & 0.74 & 0.875 & 33.0 & 1.5 \\
\hline 3 & SPJ 53-21-77-20-1 & 163 & 125 & 9.8 & 24.25 & 205.5 & 83.6 & 22.62 & 17.95 & 0.74 & 0.885 & 30.0 & 1.6 \\
\hline 4 & SPJ 53-21-77-13-1 & 171 & 124 & 8.9 & 23.25 & 208.4 & 84.9 & 22.74 & 18.15 & 0.75 & 0.865 & 29.0 & 1.4 \\
\hline 5 & SPJ 53-21-77-15-1 & 158 & 130 & 9.4 & 24.2 & 207.5 & 83.2 & 22.61 & 20.15 & 0.74 & 0.885 & 35.0 & 1.7 \\
\hline 6 & SPJ 53-21-77-12-1 & 153 & 122 & 9.6 & 23.25 & 200.5 & 86.3 & 23.05 & 18.60 & 0.75 & 0.875 & 35.0 & 1.6 \\
\hline 7 & SPJ 53-21-77-25-8 & 152 & 129 & 8.4 & 22.8 & 199.3 & 84.6 & 22.85 & 19.65 & 0.75 & 0.875 & 37.5 & 1.5 \\
\hline 8 & SPJ 53-21-77-25-7 & 175 & 125 & 10.2 & 23.95 & 203.5 & 86.1 & 23.65 & 18.80 & 0.75 & 0.875 & 35.0 & 1.5 \\
\hline 9 & SPJ 53-21-77-25-6 & 153 & 123 & 10.1 & 23.95 & 208.5 & 85.2 & 21.95 & 18.95 & 0.74 & 0.865 & 37.0 & 1.4 \\
\hline 10 & SPJ 53-21-77-25-4 & 176 & 124 & 10.6 & 22.9 & 200.5 & 83.8 & 23.21 & 17.55 & 0.75 & 0.890 & 34.0 & 1.6 \\
\hline 11 & SPJ 53-21-77-27-4 & 176 & 130 & 9.4 & 23.95 & 203.2 & 85.5 & 21.85 & 17.85 & 0.74 & 0.865 & 36.0 & 1.7 \\
\hline 12 & SPJ 53-21-77-35-2 & 174 & 124 & 10.3 & 23.6 & 208.2 & 85.4 & 22.15 & 18.85 & 0.74 & 0.875 & 36.0 & 1.6 \\
\hline 13 & SPJ 53-21-77-56-8 & 178 & 123 & 9.8 & 25.15 & 205.5 & 84.6 & 21.75 & 17.55 & 0.74 & 0.885 & 38.0 & 1.5 \\
\hline 14 & SPJ 53-21-77-35-3 & 179 & 124 & 11.2 & 23.4 & 203.1 & 86.1 & 20.52 & 18.75 & 0.74 & 0.890 & 29.0 & 1.4 \\
\hline 15 & SPJ 53-21-77-51-5 & 162 & 130 & 10.3 & 24.25 & 200.5 & 85.5 & 21.8 & 17.95 & 0.72 & 0.885 & 32.0 & 1.5 \\
\hline 16 & SPJ 53-21-77-51-4 & 154 & 122 & 9.5 & 25.05 & 196.5 & 83.5 & 20.15 & 18.35 & 0.74 & 0.865 & 33.0 & 1.6 \\
\hline 17 & SPJ 53-21-77-51-2 & 166 & 127 & 10.1 & 25.05 & 196.5 & 87.2 & 22.25 & 18.15 & 0.72 & 0.890 & 34.0 & 1.7 \\
\hline 18 & SPJ 53-21-77-51-8 & 155 & 130 & 10.5 & 25.05 & 198.5 & 86.5 & 22.75 & 18.85 & 0.73 & 0.885 & 33.0 & 1.5 \\
\hline 19 & SPJ 53-21-77-51-7 & 171 & 124 & 10.9 & 25.15 & 204.5 & 88.1 & 20.95 & 18.25 & 0.74 & 0.875 & 34.0 & 1.5 \\
\hline 20 & SPJ 53-21-77-51-3 & 153 & 126 & 8.8 & 24.32 & 208.5 & 84.8 & 21.85 & 18.35 & 0.74 & 0.885 & 34.0 & 1.7 \\
\hline 21 & CRMAS 2232-85 & 105.5 & 105 & 12.0 & 24.15 & 218.4 & 84.5 & 18.85 & 20.50 & 0.72 & 0.840 & 34.0 & 2.0 \\
\hline \multirow[t]{3}{*}{22} & Jalmagna & 174 & 130 & 9.0 & 24.95 & 186.7 & 85.5 & 23.25 & 17.35 & 0.75 & 0.880 & 28.0 & 1.5 \\
\hline & $\mathrm{LSD}_{5 \%}$ & 14.79 & & 3.075 & 1.62 & 45.12 & 7.02 & 1.65 & 4.52 & 0.82 & 0.110 & 5.83 & 0.412 \\
\hline & $\mathrm{CV} \%$ & 4.45 & & 14.1 & 3.28 & 10.86 & 4.12 & 3.95 & 12.39 & 5.39 & 6.34 & 7.28 & 12.2 \\
\hline
\end{tabular}


similar to the kind of popular variety Jalmagna by integrating molecular markers in the breeding program is highly desirable as that can be achieved in relatively short time period compared with conventional breeding. Further, utilization of the RGA facility hasten the duration of breeding cycle in case of long duration genotype. In this experiment, lines with pyramided genes exhibited higher levels of tolerance against the tested virulent $X$. oryzae pv. oryzae isolates. Development of pyramided lines through marker-assisted selection successfully have been reported earlier illustrating less duration, more precision and more environment friendly (Dokku et al. 2013; Huang et al. 1997; Narayanan et al. 2004; Perez et al. 2008; Pradhan et al. 2015a, b; Rajpurohit et al. 2011; Sanchez et al. 2000; Singh et al. 2001; Suh et al. 2013; Sundaram et al. 2008). The pyramided lines with two gene combinations expressed higher levels of resistance in comparison with the susceptible cultivar Jalmagna. The results suggest that two gene combinations with $\mathrm{Xa21+xa13}$ pyramided lines had higher resistance level with shorter lesions lengths followed by $X a 21+x a 5$ containing lines than the recipient variety. Lines with $X a 21$ in combination with either $x a 13$ or $x a 5$ had shown better tolerance disease reaction. The utility of $\mathrm{Xa21}$ in achieving higher levels of resistance in rice has been reported earlier (Huang et al.1997; Sanchez et al. 2000; Singh et al. 2001; Sridhar et al. 1999) and the synergistic action and/or quantitative complementation between the resistant genes might result in enhanced levels of resistance (Sanchez et al. 2000).

The recovery of higher percentage of recurrent parent genome with less drag in $\mathrm{BC}_{3} \mathrm{~F}_{1}$ was achieved using 60 polymorphic
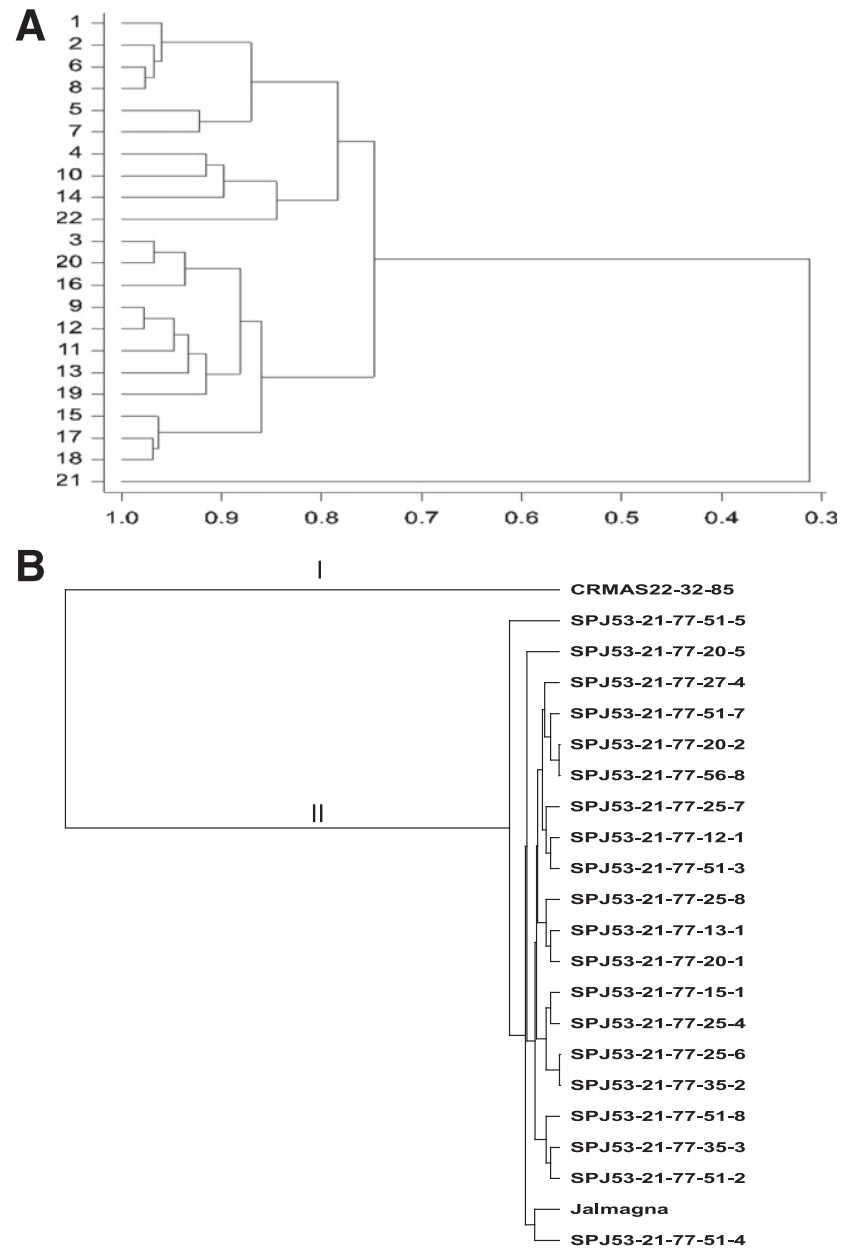

Fig. 3. Dendrogram illustrating the genetic relationship between parents and 20 pyramided lines based on A,12 agro-morphological traits using Euclidean type of test by Furthest Neighbor method. B, Genotype numbers used are listed in Table 3 and dendrogram is based on 60 microsatellite markers. primers. This is very much in line with earlier marker-assisted selection product development reports (Dokku et al. 2013; Perez et al. 2008; Pradhan et al. 2015a, b; Rajpurohit et al. 2011; Suh et al. 2013; Sundaram et al. 2008). Following this approach, after three backcross generations, it was possible to identify plants carrying the recurrent parent genome of more than $95 \%$ in the pyramided lines. In the $\mathrm{BC}_{3} \mathrm{~F}_{3}$ generation, 20 pyramided lines homozygous for both $x a 13$ plus $X a 21$, and $x a 5$ plus $X a 21$ were obtained exhibiting maximum recurrent parent genome recovery. There is a variation in the theoretically expected value of contribution from the recurrent parent genome to the $\mathrm{BC}_{1} \mathrm{~F}_{1}$ plants and in other backcross generations. As per reports of Sundaram et al. (2008), there may be a "pull" for introgression of the Xa21, xa13, and xa5 genes during selection which favors inheritance of additional unlinked loci from the donor genome in $\mathrm{BC}_{1} \mathrm{~F}_{1}$ plants and $\mathrm{BC}_{2} \mathrm{~F}_{1}$ generation. However, we found no pull effect during the transfer of $\mathrm{Xa21}$, xa13, and $x a 5$ genes in different backcross generations.

Complete transfer of the agro-morphologic, grain quality and yield traits of the recipient variety to the pyramided lines containing $\mathrm{BB}$ tolerance genes from donor was the target in gene pyramiding work through marker-assisted backcross breeding approach. The results of recurrent parent genome contribution indicated that genotypes SPJ 53-21-77-13-1, SPJ 53-21-77-25-4, and SPJ 53-2177-56-8 possessing $\mathrm{Xa21}$ and $\mathrm{xa13}$ resistance genes combination and SPJ 53-21-77-51-4 and SPJ 53-21-77-51-2 containing Xa21 and $x a 5$ gene pyramids had $95 \%$ of the recurrent parent genome content (Table 3). Further, graphical genotyping data of the pyramided lines also indicated that no linkage drag was observed in chromosome 8 carrying $x a 13$ (Fig. 5A). Besides, no drag was found in four lines (SPJ 53-21-77-51-4, SPJ 53-21-77-51-5, SPJ 53-21-77-51-7, and SPJ 53-21-77-51-8) for $x a 5$ carrier chromosome in Xa21+xa5 pyramided lines (Fig. 5B). Similar results were obtained in earlier studies with accelerated recovery of recurrent parent genome and less donor segment drag suggesting the importance of more number of background markers (Dokku et al. 2013; Pradhan et al. 2015b; Suh et al. 2013; Sundaram et al. 2008). No genetic linkage drag was observed for the transfer of genes Xa21, xa13, and $x a 5$ (Fig. 5) as the donor parent was a derivative of mega variety Swarna, which has less undesirable effects than using a wild or landrace type of donor source for BB resistance genes. The mega variety Swarna is

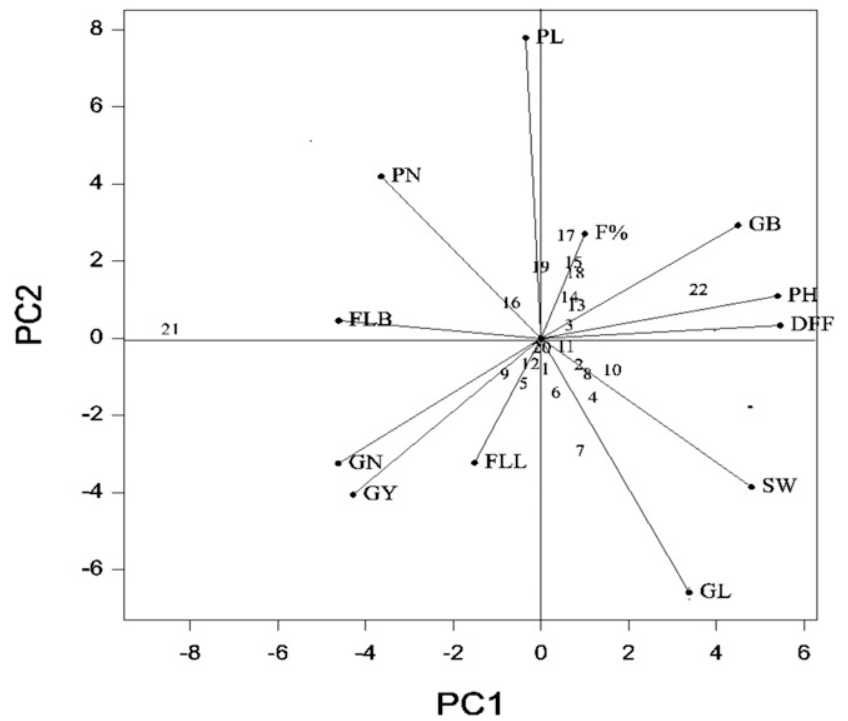

Fig. 4. Genotype-by-trait biplot analysis of 20 pyramided lines containing two gene combinations $(X a 21+x a 13$ and $X a 21+x a 5)$ along with parents for first two principal components. The numbers in the figure represent the serial number of the genotypes listed in Table 3. DFF, days to 50\% flowering; $\mathrm{PH}$, plant height (cm); FLL, flag leaf length (cm); FLB, flag leaf breadth; PN, panicles/plant; PL, panicle length; GL, grain length; GB, grain breadth; TW, seed test weight; SF, spikelet fertility; SN, spikelets/panicle; and GY, grain yield. 
a highly adapted variety for the favorable ecology. Results indicated that a broad-based highly adapted variety as a source of donor might give better performance and less drag compared with the wild and land races as donor (Pradhan et al. 2015b). It is expected that all the favorable genes are accumulated in the mega variety and subsequently transfer of these genes would help in further improving the background of the pyramided lines. The approach used in the study ensured the realization of the major objective resulting in development of a cultivar with enhanced resistance to $\mathrm{BB}$ and accelerated recovery of recurrent genome with better yield.

Evaluation of 20 pyramided lines along with their parents for yield and agro-morphologic traits exhibited excellent features of recurrent parent and also yielding ability of recipient parent with tolerance to $\mathrm{BB}$ resistance in the developed pyramided lines. In genotype-trait biplot analysis, the donor parent is placed away from the origin, indicating that lesser genetic drag segment recovered from donor and majority of the traits are from recipient parent (Fig. 4). As the recipient parent is not much away from the center, the pyramided lines with similar in phenotype are expected to be near the origin. On the other hand, the genotypes located near the origin indicated their better stability compared with the distant ones. The high yielding capacity of the pyramided lines even more than recipient parent might have achieved by the use of donor parent of mega variety Swarna derivative (CRMAS 2232-85) which might have contributed some yield traits or QTLs. Consequently, the complete recovery of yield and grain quality traits of Jalmagna along with more grain yield and exhibiting tolerance to $\mathrm{BB}$ disease is a very significant achievement. Utilization of sufficient number of background polymorphic markers in the breeding program helped to recover very high recipient parent genome content. The genotyping results and its further analysis indicated that the contribution of recurrent genome was higher in few backcross derivatives than the theoretical expected value of $75 \%$ in $\mathrm{BC}_{1} \mathrm{~F}_{1}$ (Table 3 ) and $87 \%$ in $\mathrm{BC}_{2} \mathrm{~F}_{1}$ generation. In $\mathrm{BC}_{3} \mathrm{~F}_{3}$, the genome content of Jalmagna in selected derivatives (SPJ 53-21-77-13-1, SPJ 53-21-77-25-4, SPJ 5321-77-56-8, SPJ 53-21-77-51-2, and SPJ 53-21-77-51-4) was as high as $95 \%$. The background selections with many molecular markers accelerated the recovery of recurrent genome content in a backcross breeding program and further indicate that selection for resistance gene combinations of $\mathrm{Xa21}$ with $x a 13$ and $x a 5$ genes may not give antagonistic effects for yield and other traits (Dokku et al. 2013; Pradhan et al. 2015b; Suh et al. 2013).

The performance evaluation of $\mathrm{BC}_{3} \mathrm{~F}_{3}$ pyramided lines showed that, all the pyramided lines had registered higher grain yield than the recipient parent Jalmagna with similar agro-morphological and grain quality features of recipient parent. The higher level of tolerance to $\mathrm{BB}$ disease and the absence of any yield penalty due to accumulation of resistance genes in the pyramids offer confidence in integrating application of molecular markers in classical breeding for selection of the desired trait(s) and recovery of the recurrent parental genome. Deployment of a two gene combination like $x a 21+$ $X a 13$ and $X a 21+x a 5$ can achieve higher level of tolerance in many $\mathrm{BB}$ prone rice growing areas of the country. The study clearly establishes the success of marker-assisted selection in precise breeding of recessive and dominant genes for resistance and providing higher level of tolerance to the most destructive diseases of rice in a long-duration, photosensitive, lowland rice cultivar.

Performance of the pyramided lines indicated that using functional markers in marker-assisted backcross program is a reliable approach for pyramiding BB resistance genes in rice. We were successful in identifying superior BB pyramided lines with higher level of resistance to the disease in a long-duration,
A

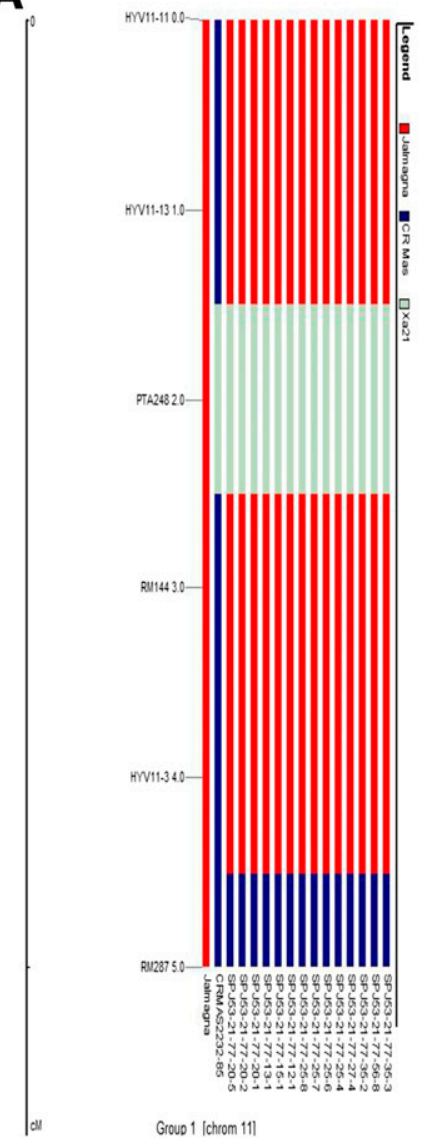

B

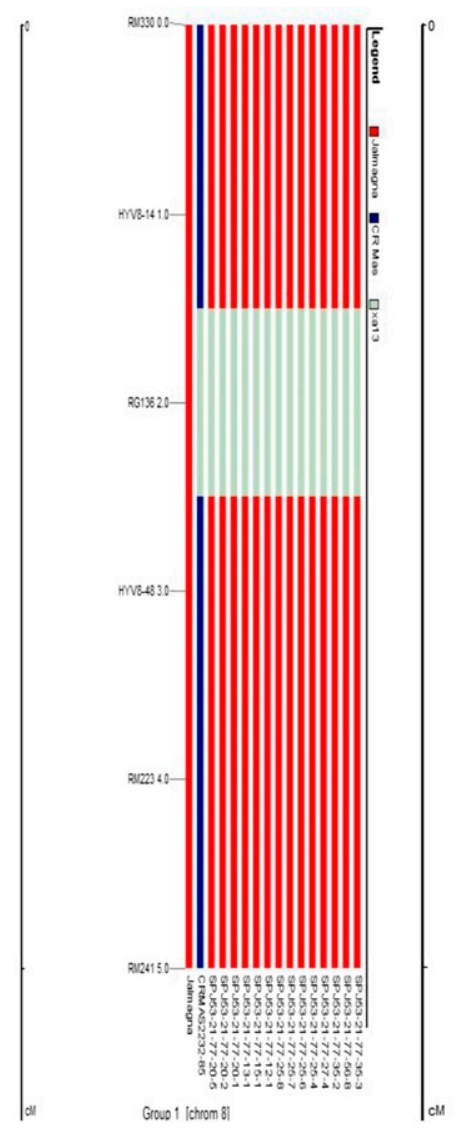

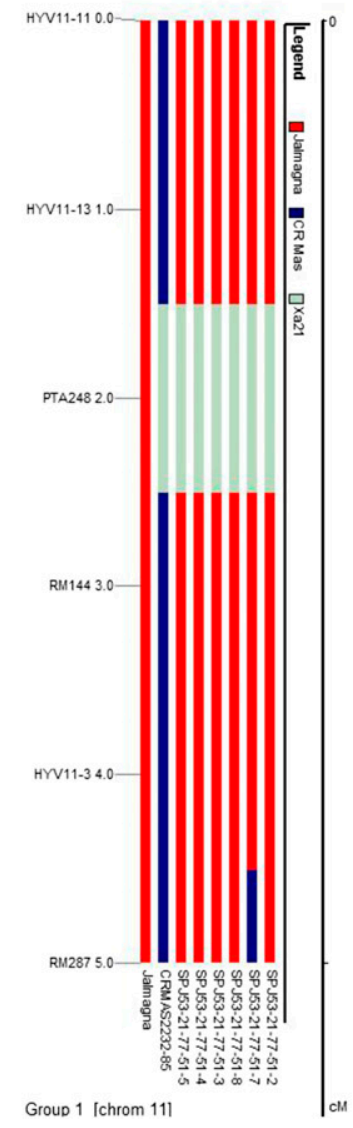

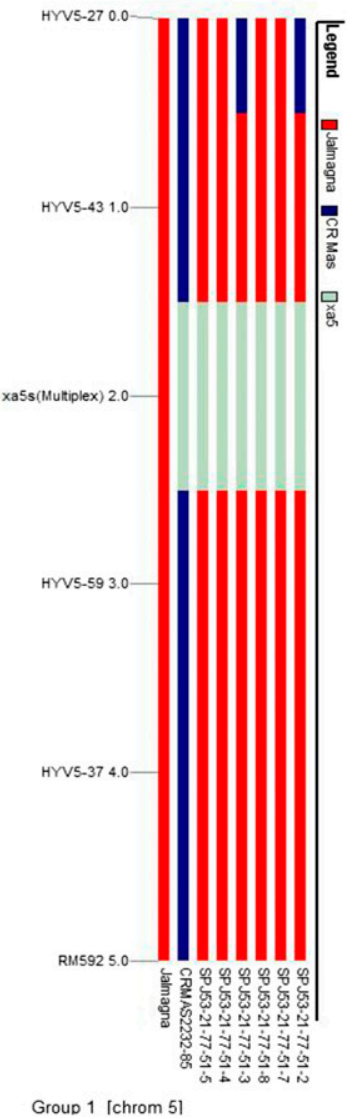

Fig. 5. Analysis of genome introgression of 20 pyramided lines containing two bacterial blight resistant genes A, Xa21 on chromosome 11 and xa13 on chromosome 8 in $14 \mathrm{BC}_{3} \mathrm{~F}_{3}$ pyramided lines and $\mathbf{B}, \mathrm{Xa21}$ on chromosome 11 and $x a 5$ on chromosome 5 in six $\mathrm{BC}_{3} \mathrm{~F}_{3}$ pyramided lines developed from backcross breeding of Jalmagna and CRMAS 2232-85. 
photosensitive, lowland rice cultivar. These BB pyramided breeding lines may provide a solution in the BB endemic areas of the country. These lines can be further nominated for multilocation testing for their performance and release as varieties in the country or can be used as potential BB resistance donors. Development of two gene combination resistance compared with single gene deployment against the bacterial disease in the Indian subcontinent is an important achievement as the chance of breakdown of resistance in single gene deployment is very high. The rich diversity of various agro-climatic zones of the country maintains number of genetically distinct virulent $X$. oryzae pv. oryzae strains. Therefore, these BB pyramided lines are expected to have a high impact on the yield stability and sustainability of lowland rice ecology particularly in the eastern region of the country where the majority of the rice areas are rain-fed lowlands.

\section{ACKNOWLEDGMENTS}

We thank R. Thakur, former scientist, ICRISAT, and P. Nayak, former Editor-In-Chief, Oryza for their valuable suggestions for improvement of the manuscript. We also thank Director and Head Crop Improvement Division, National Rice Research Institute for providing all the necessary facilities. The work was supported by a grant from Department of Biotechnology, Government of India.

\section{LITERATURE CITED}

Amante-Bordeos, A., Sitch, L., Nelson, R., Dalmacio, R., Oliva, N., Aswidinnoor, H., and Leung, H. 1992. Transfer of bacterial blight and blast resistance from the tetraploid wild rice Oryza minuta to cultivated rice, Oryza sativa. Theor. Appl. Genet. 84:345-354.

Bharatkumar, S., Paulraj, R. S. D., Brindha, P. V., Kavitha, S., and Gnanamanickam, S. S. 2008. Improvement of bacterial blight resistance in rice cultivars Ajayothi and IR50 via marker-assisted backcross breeding. J. Crop Improv. 21:101-116.

Bhasin, H., Bhatia, D., Raghuvanshi, S., Lore, S. J., Gurpreet, K., Sahi, K. G., Kaur, B., Vikal, Y., and Singh, K. 2012. New PCR-based sequence-tagged site marker for bacterial blight resistance gene Xa38 of rice. Mol. Breed. 30: 607-611.

Chu, Z., Fu, B., Yang, H., Xu, C., Li, Z., Sanchez, A., Park, Y. J., Bennetzen, J. L., Zhang, Q., and Wang, S. 2006. Targeting xa13, a recessive gene for bacterial blight resistance in rice. Theor. Appl. Genet. 112:455-461.

Dellaporta, S. L., and Wood, J. 1983. A plant DNA minipreparation: Version II. Plant Mol. Biol. Rep. 1:19-21.

Dokku, P., Das, K. M., and Rao, G. J. N. 2013. Pyramiding of four resistance genes of bacterial blight in Tapaswini, an elite rice cultivar, through markerassisted selection. Euphytica 192:87-96.

Gu, K., Sangha, J. S., Li, Y., and Yin, Z. 2008. High resolution genetic mapping of bacterial blight resistance gene Xa10. Theor. Appl. Genet. 116: 155-163.

Hampl, V., Pavlicek, A., and Flegr, J. 2001. Construction and bootstrap analysis of DNA fingerprinting based phylogenetic trees with the freeware program FreeTree: Application to trichomonad parasites. Int. J. Syst. Evol. Microbiol. 51:731-735.

Han, X., Yang, Y., Wang, X., Zhou, J., Zhang, W., Yu, C., Cheng, C., Cheng, Y., and Yan, C. 2014. Quantitative trait loci mapping for bacterial blight resistance in rice using bulked segregant analysis. Int. J. Mol. Sci. 15: 11847-11861.

Hu, K. M., Qiu, D. Y., Shen, X. L., Li, X. H., and Wang, S. P. 2008. Isolation and manipulation of quantitative trait loci for disease resistance in rice using a candidate gene approach. Mol. Plant 1:786-793.

Huang, N., Angeles, E. R., Domingo, J., Magpantay, G., Singh, S., Zhang, G., Kumaravadevil, N., Bennett, J., and Khush, G. S. 1997. Pyramiding of bacterial blight resistance genes in rice: Marker assisted selection using RFLP and PCR. Theor. Appl. Genet. 95:313-320.

Ismail, A. M., Singh, U. S., Singh, S., Dar, M. H., and Mackill, D. J. 2013. The contribution of submergence-tolerant (Sub1) rice varieties to food security in flood-prone rain-fed lowland areas in Asia. Field Crops Res. 152:83-93

Joseph, M., Gopalakrishnan, S., and Sharma, R. K. 2004. Combining bacterial blight resistance and basmati quality characteristics by phenotypic and molecular marker assisted selection in rice. Mol. Breed. 13:377-387.

Kauffman, H. E., Reddy, A. P. K., Hsien, S. P. Y., and Merca, S. D. 1973. An improved technique for evaluating resistance of rice varieties to Xanthomonas oryzae. Plant Dis Rep. 57:537-541.
Khush, G. S., Mackill, D. J., and Sidhu, G. S. 1989. Breeding rice for resistance to bacterial leaf blight. Pages 207-217 in: Bacterial Blight of Rice. IRRI, Manila, Philippines.

Khush, G. S. 2005. What it will take to feed 5.0 billion rice consumers in 2030. Plant Mol. Biol. 59:1-6.

Narayanan, N. N., Baisakh, N., Oliva, N. P., VeraCruz, C. M., Gnanamanickam, S. S., Datta, K., and Datta, S. K. 2004. Molecular breeding: Marker-assisted selection combined with biolistic transformation for blast and bacterial blight resistance in indica rice (cv. CO39). Mol. Breed. 14:61-71.

Page, R. D. 1996. TreeView: An application to display phylogenetic trees on personal computers. Comput. Appl. Biosci. 12:357-358.

Pavalíce, A., Hrda, S., and Flegr, J. 1999. Free Tree-freeware program for construction of phylogenetic trees on the basis of distance data and bootstrap/ jackknife analysis of the tree robustness. Application in the RAPD analysis of genus Frenkelia. Folia Biol. (Praha) 45:97-99.

Perez, L. M., Redona, E. D., Mendioro, M. S., Vera Cruz, C. M., and Leung, H. 2008. Introgression of $\mathrm{Xa} 4, \mathrm{Xa} 7$ and $\mathrm{Xa} 21$ for resistance to bacterial blight in thermo-sensitive genetic male sterile rice (Oryza sativa L.) for the development of two-line hybrids. Euphytica 164:627-636.

Pha, P. N., and Lang, N. T. 2004. Marker assisted selection in rice breeding for bacterial leaf blight. Omon Rice 12:19-26.

Pradhan, S. K., Nayak, D. K., Pandit, E., Barik, S. R., Mohanty, S. P., Anandan, A., and Reddy, J. N. 2015a. Characterization of morpho-quality traits and validation of bacterial blight resistance in pyramided rice genotypes under various hotspots of India. Aust. J. Crop Sci. 9:127-134.

Pradhan, S. K., Nayak, D. K., Mohanty, S., Behera, L., Barik, S. R., Pandit, E., and Lenka, S. 2015b. Pyramiding of three bacterial blight resistance genes for broad-spectrum resistance in deepwater rice variety, Jalmagna. Rice (N.Y.) $8: 19$.

Rajpurohit, D., Kumar, R., Kumar, M., Paul, P., Awasthi, A. A., Basha, P. O., Puri, A., Jhang, T., Singh, K., and Dhaliwal, H. S. 2011. Pyramiding of two bacterial blight resistance and a semi dwarfing gene in Type 3 Basmati using marker-assisted selection. Euphytica 178:111-126.

Rao, K. K., Lakshminarasu, M., and Jena, K. K. 2002. DNA markers and marker-assisted breeding for durable resistance to bacterial blight disease in rice. Biotechnol. Adv. 20:33-47.

Sanchez, A. C., Brar, D. S., Huang, N., and Khush, G. S. 2000. Sequence tagged site markers-assisted selection for three bacterial blight resistance genes in rice. Crop Sci. 40:792-797.

SAS Institute Inc. 2010. Page 626 in: SAS 9.2 Language Reference: Concepts, 2nd Ed. SAS Institute Inc., Cary, NC.

Shanti, M. L., George, M. L. C., Vera Cruz, C. M., Bernardo, M. A., Nelson, R. J., Leung, H., Reddy, J. N., and Sridhar, R. 2001. Identification of resistance genes effective against bacterial leaf blight pathogen in eastern India. Plant Dis. 85:506-512.

Singh, S., Sidhu, J. S., Huang, N., Vikal, Y., Li, Z., Brar, D. S., Dhaliwal, H. S., and Khush, G. S. 2001. Pyramiding three bacterial blight resistance genes (xa-5, $x a-13$ and $X a-21)$ using marker-assisted selection into indica rice cultivar PR-106. Theor. Appl. Genet. 102:1011-1015.

Sonti, R. V. 1998. Bacterial leaf blight of rice: New insights from molecular genetics. Curr. Sci. 74:206-212.

Sridhar, R., Reddy, J. N., Singh, U. D., and Agrawal, P. K. 1999. Usefulness of combinations of bacterial blight resistance genes at Cuttack, Orissa, India. IRRN 24:24-25

Suh, J. P., Jeung, J. U., Noh, T. H., Cho, Y. C., Park, S. H., Park, H. S., Shin, M. S., Kim, C. K., and Jena, K. K. 2013. Development of breeding lines with three pyramided resistance genes that confer broad-spectrum bacterial blight resistance and their molecular analysis in rice. Rice (N.Y.) 6:5.

Sundaram, R. M., Laha, G. S., Viraktamath, B. C., Sujatha, K., Natarajkumar, P., Hari, Y., Srinivasa, R. K., Reddy, C. S., Balachandran, S. M., Madhav, M. S., Hajira, S. K., Rani, N. S., Vishnupriya, M. R., and Sonti, R. V. 2011. Marker assisted breeding for development of bacterial blight resistant rice. Pages 154-182 in: Genomics and Crop Improvement: Relevance and Reservations. K. Muralidharan and E. A. Siddiq, eds. Institute of Biotechnology, Acharya NG Ranga Agricultural University, Hyderabad, India.

Sundaram, R. M., Vishnupriya, M. R., Biradar, S. K., Laha, G. S., Reddy, G. A., Rani, N. S., Sarma, N. P., and Sonti, R. V. 2008. Marker assisted introgression of bacterial blight resistance in Samba Mahsuri, an elite indica rice variety. Euphytica 160:411-422.

Van Berloo, R. 1999. GGT: Software for display of graphical genotypes. J. Hered. 90:328-330.

Yoshimura, S., Yoshimura, A., Iwata, N., McCouch, S. R., Abenes, S. L., Baraoidan, M. R., Mew, T. W., and Nelson, R. J. 1995. Tagging and combining bacterial blight resistance genes in rice using RAPD and RFLP markers. Mol. Breed. 1:375-387.

Zhang, F., Huang, L., Zhang, F., Hu, D., Wu, W., Wang, W., Ali, J., Vera Cruz, C., Zhou, Y. L., and Li, Z. 2014. Interacting transcriptomes revealing molecular mechanisms underlying Xa39 mediated broad spectrum resistance of rice to bacterial blight. Plant Genome 8:3. 